\title{
Agreement urged on access to DNA databases
}

Paris. A French government committee set up to study the commercial use of DNA banks last week suggested that the scientists who created such a bank should enjoy privileged access for a period of three years.

After this, however, the committee said that the body that had paid for the bank (referred to as the 'sponsor') should have the right to open it to a third party. In a separate move, it has also called for a formal international agreement guaranteeing open access to all DNA sequence databases.

The committee was set up earlier this year following a public row over a proposal that would have given Millennium, a Massachusetts-based biotechnology company, exclusive access to a DNA bank held at the Centre d'Etudes du Polymorphisme Humain (CEPH) in Paris (see Nature 368, 175; 1994).

Philippe Froguel, the researcher who developed the bank from samples collected from more than 800 French families with a history of non-insulin-dependent diabetes, objected strongly to the proposal, accusing Daniel Cohen, the director of CEPH, of trying to "sell" the bank. Froguel, dismissed as a result of the dispute, argued that he should have control over access to the bank.

The committee's compromise acknowledges that the sponsor of a DNA bank should have 'legal responsibility' for it. But it also recommended that the researchers who built the bank should have a period in which to exploit the bank themselves.

According to the committee, the lack of clear contractual arrangements contributed directly to the CEPH dispute. It recommended that a new commission should be set up to approve all research on DNA sequences, assessing the scientific and ethical need for a bank, ensuring that the terms of its eventual commercialization are explicitly agreed at the start of a project and arbitrating on any conflicts that arise.

In line with France's recently adopted bioethics bill (see Nature 369, 599; 1994), the committee said that donors to DNA banks should not be paid, nor be entitled to any royalties on the use of their DNA. But it also proposed that donors must agree to any use made of their DNA, in particular in commercially oriented applications.

The committee's recommendations on databases of DNA sequences that cannot be traced to individual donors are very different. Such databases, it says, represent "an international instrument of cooperation and diffusion of knowledge", and must be shared from the outset.

The committee calls for a formal international agreement guaranteeing open access to all sequence databases, and defining the terms under which their costs and the construction are shared. Those supplying sequences to international databases would be given a 'copyright' acknowledging the originality of their contribution.

The report's recommendations on DNA banks, which are likely to be accepted as a reasonable compromise on all sides, will probably be introduced as decrees - expected to be applied retroactively - in the autumn.

Declan Butler

\section{Généthon builds up 'genetic valley'}

Paris. The Généthon laboratory near Paris and the biotechnology start-up company Genset last week launched a joint FFr600 million (US\$11 million) programme to sequence and analyse all the regulatory regions of the human genome by the end of 1996.

Their aim is to identify transcription factors that activate genes, as well as their binding sites. Genset markets oligonucleotide-based products, and has developed transcription factor decoys - short DNA sequences that mimic regulatory sequences - which it hopes will compete with endogenous binding sites, preventing transcription factors from activating genes involved in disease.

Généthon was set up in 1990 jointly by the French Muscular Dystrophy Association (AFM) and the Centre d'Etudes du

\section{Caution urged on genome manipulation}

Paris. Pierre Chambon, the eminent French biologist and geneticist, last week called for a global moratorium lasting 50 years on all germ line manipulations of the human genome.

Writing in the newspaper Le Monde, Chambon, who was recently appointed to the chair of molecular genetics at the Collège de France in Paris, congratulated molecular biology on its progress over the past 40 years in unravelling the fundamental mechanisms of life.

But he expressed concern that transgenesis (genetic manipulation) could, by allowing directed genetic change, open the way to "an era of Lamarckian biological evolution". Chambon argued that although such applications are still "science fiction", the situation could change rapidly, for example if genes that delayed ageing

were to be discovered.

Biologists, warned Chambon, often show "unreflected optimism" about the nature of, and delay in, the application of their discoveries. But he also attacked the "emotive"

IMAGE
UNAVAILABLE
FOR
COPYRIGHT
REASONS

arguments of pressure groups, calling for modern biology to be given a central place in the school curriculum.

A "period of reflection" is needed, said Chambon. He argued that "a 50 year global moratorium on manipulations of the human genome would seem to me a wise decision".
Polymorphisme Humain (CEPH). Based at AFM's headquarters at Évry outside Paris, the laboratory has rapidly become one of Europe's leading gene mapping centres, having produced complete genetic and physical maps of the human genome.

Under their agreement, the two organizations will create a joint Trés Grand Séquençage (TGS) laboratory at the Evry site. Twenty-five people will start work using Généthon's existing facilities, but they will have their own building next year. Jean Weissenbach, scientific director of Généthon, and Marc Vasseur, chief scientific officer at Genset, will lead the project.

Généthon's strategic alliance with Genset, in which it will take a FFr 10 million stake, is its first with a private company. The move is part of a plan to build a network of such alliances - known as GénéthonIndustries - and create a 'genetic valley' at the Evry site. Several small French biotechnology companies have already expressed interest in moving to Évry.

AFM wants these companies to collaborate in the recently launched Généthon 2 programme, aimed at identifying genes, and the planned Généthon 3 programme, which would work out their role and function. AFM's overall goal is to speed up the development of genome therapeutics.

Généthon is already collaborating with Rhône-Poulenc Rorer (RPR) and is likely to become part of the company's planned gene therapy network.

At the launch of TGS, Bernard Barateau, the president of AFM, criticized the government for its "absence of a clear strategy [in research] on the human genome", and called on it to launch a big "Génome-Santé" programme. Only by coordinating public and private funds can France - and Europe compete internationally, says Barateau. A parliamentary study group is said to support Barateau's strategy. 